\title{
1 Genomic islands of heterozygosity maintained across caribou populations
}

\section{2 despite inbreeding}

3 Maintenance of heterozygosity despite inbreeding

$4 \quad$ Kirsten Solmundson ${ }^{1}$ | Jeff Bowman ${ }^{1,2 *} \mid$ Paul J. Wilson $^{3 *} \mid$ Rebeca S. Taylor $^{3}$ | Rebekah L.

$5 \quad$ Horn $^{3}$ | Sonesinh Keobouasone ${ }^{4}$ | Micheline Manseau ${ }^{1,4^{*}}$

$6{ }^{1}$ Environmental \& Life Sciences Graduate Program, Trent University, 1600 West Bank Drive,

7 Peterborough, ON, K9L 0G2, Canada

$8 \quad{ }^{2}$ Wildlife Research and Monitoring Section, Ontario Ministry of Natural Resources and Forestry, Trent

9 University, DNA Building, Peterborough, ON K9L 0G2, Canada.

$10{ }^{3}$ Biology Department, Trent University, 1600 West Bank Drive, Peterborough, ON K9J 7B8, Canada.

$11{ }^{4}$ Landscape Science and Technology Division, Environment and Climate Change Canada, 1125 Colonel

12 By Drive, Ottawa, ON K1S 5R1, Canada.

$13 *$ Co-Principal Investigators

\section{Correspondence}

15 Kirsten Solmundson, Environmental and Life Sciences, Trent University, 1600 West Bank Drive,

16 Peterborough, ON K9J 7B8, Canada.

17 E-mail: kirstensolmundson@ trentu.ca

\section{Present address}

19 Rebekah L. Horn, Hagerman Genetics Laboratory, 3059F National Fish Hatchery Road, Hagerman, Idaho, 20 83332, USA.

\section{Funding information}

22 NSERC Collaborative Research \& Development (CRD) grant to P.J.W., NSERC CREATE and Discovery

23 grants to J.B. and P.J.W., and a Garfield Weston Foundation Fellowship, Ontario Graduate Scholarships,

24 and Ontario Species at Risk Stewardship Program funding to K.S. 


\section{Abstract}

27 Small, isolated populations are prone to inbreeding, increasing the proportion of homozygous

28 sites across the genome that can be quantified as runs of homozygosity (ROH). Caribou

29 (Rangifer tarandus) are declining across their range in Canada; thus, understanding the effects of

30 inbreeding on genetic potential is pertinent for conserving small, isolated populations. We

31 quantified $\mathrm{ROH}$ in high-coverage whole genomes of boreal caribou from small, isolated

32 populations in southern Ontario, Canada, in comparison to caribou from the continuous range of

33 Ontario, other caribou ecotypes in Canada, and western Greenland. Sampled populations

34 presented divergent evolutionary histories, differing population sizes, and extents of isolation.

35 We conducted BLAST searches across regions of elevated heterozygosity to identify genes that

36 have maintained variation despite inbreeding. We found caribou from recently isolated

37 populations in Ontario had a large proportion of their genome in long $\mathrm{ROH}$. We observed even

38 larger proportions but shorter $\mathrm{ROH}$ in western Greenland, indicating that inbreeding has occurred over a longer period in comparison to other populations. We observed the least inbreeding in barren-ground and eastern migratory caribou, which occur in larger population sizes than boreal

41 caribou. Despite vastly different inbreeding extents, we found regions of high heterozygosity

42 maintained across all populations. Within these islands of heterozygosity, we identified genes

43 associated with immunity, signaling regulation, nucleotide binding, toxin elimination, and

44 feeding behaviour regulation. In this study, we confirm inbreeding in isolated populations of a

45 species at risk, but also uncover high variation in some genes maintained across divergent

46 populations despite inbreeding, suggesting strong balancing selection. 


\section{KEYWORDS}

49 Runs of homozygosity, inbreeding, islands of heterozygosity, balancing selection, conservation genomics, 50 caribou

\section{1 | INTRODUCTION}

Small and isolated populations have limited mate choice, which increases the likelihood

54 of inbreeding (Herfindal et al., 2014). One consequence of inbreeding is increased genome-wide

55 homozygosity, which can be quantified as the proportion of the genome in runs of homozygosity

56 (ROH; Szpiech et al., 2013). ROH measure the genomic level of inbreeding without making

57 assumptions about the founders of the populations, and therefore can provide a more accurate

58 estimate of inbreeding than traditional methods, such as a pedigree (Kardos, Luikart, \&

59 Allendorf, 2015). ROH have been used to study the consequences of persisting in small and

60 isolated populations, such as the loss of genetic diversity and increased inbreeding that preceded

61 the extinction of an island population of woolly mammoth (Mammuthus primigenius;

62 Palkopoulou et al., 2015). More recently, ROH have been used to investigate inbreeding in

63 species of conservation concern. A study of a Scandinavian wolf (Canis lupus) population

64 revealed stretches of $\mathrm{ROH}$ throughout the genome of wolves born in an isolated population,

65 whereas in immigrant wolves $\mathrm{ROH}$ were rare or absent (Kardos et al., 2018). Knowledge of $\mathrm{ROH}$

66 that are shared, or identical by descent, between individuals or populations is vital for designing

67 mitigation plans and identifying potential candidates for translocations for at-risk species, as

68 demonstrated by a recent study of isolated puma (Felis concolor) populations (Saremi et al., 69 2019). 
Inbreeding increases the probability that an individual will receive alleles that are

71 identical by descent (IBD), meaning the individual receives the same allele from both parents at a

72 particular locus, resulting in increased genome-wide homozygosity (Kardos et al., 2015). This

73 increased homozygosity can result in reduced survival or reproduction, known as inbreeding

74 depression (Hedrick \& Garcia-Dorado, 2016). Although rarely studied in wild populations,

75 inbreeding depression is well documented in captivity; for instance, in captive bred prairie-

76 chickens (Tympanuchus cupido attwateri) mortality was positively correlated with both parental

77 relatedness and the genetic inbreeding coefficient (Hammerly, Morrow, \& Johnson, 2013).

78 Inbreeding depression is caused by two genetic effects: the increased expression of recessive

79 deleterious alleles, and increased homozygosity at loci with heterozygote advantage

80 (Charlesworth \& Willis, 2009). Deleterious alleles are most likely to occur within long ROH,

81 suggesting recent inbreeding enables rare deleterious variants to exist in homozygous form,

82 resulting in inbreeding depression (Szpiech et al., 2013). The inbreeding load of a population is

83 fueled by the appearance of recessive deleterious variants, but these alleles can be purged by

84 purifying selection if given sufficient time, tempering the effects of inbreeding depression

85 (Hedrick \& Garcia-Dorado, 2016). Under intensive inbreeding, islands of high heterozygosity

86 within long homozygous stretches can indicate regions that might harbour recessive deleterious

87 alleles or be associated with heterozygote advantage under balancing selection. A study of

88 endangered brown bears (Ursus arctos marsicanus) demonstrated fixation by drift of several

89 deleterious alleles; however, high-variation was maintained in regions related to the immune

90 system, olfactory signaling pathways, and digestion despite inbreeding, suggesting balancing

91 selection prevents the loss of variation at important genes (Benazzo et al., 2017). 
93 dramatic declines in both range and population size over the past century, raising conservation

94 concerns (Festa-Bianchet, Ray, Boutin, Côté, \& Gunn, 2011; Laliberte \& Ripple, 2004). Caribou

95 are a religious, cultural, and social symbol to many Indigenous people in Canada, as well as an

96 important food source in some communities (Festa-Bianchet et al., 2011; Polfus et al., 2016).

97 Caribou diversity is described by different subspecies and ecotypes, which differ in morphology

98 and behaviour; for example, barren-ground caribou (R. t. groenlandicus) congregate in large,

99 migratory groups on the tundra (COSEWIC, 2016). Conversely, the woodland subspecies (R. $t$.

100 caribou) has several ecotypes associated with different habitats such as caribou found in the

101 mountains across western Canada (COSEWIC, 2014b), the eastern migratory caribou that

102 migrate between the boreal forest and the tundra in eastern Canada (COSEWIC, 2017a), and

103 boreal caribou that are more sedentary and found throughout the boreal forest (COSEWIC,

104 2014a). The diversity found in caribou has resulted in the classification of 12 Designatable Units

105 by the Committee on the Status of Endangered Wildlife in Canada (COSEWIC, 2011). Despite

106 this diversity, all caribou in Canada are currently listed as at risk of extinction (Special Concern,

107 Threatened, or Endangered) by COSEWIC (COSEWIC, 2014-2017).

Recent declines in caribou ranges and population sizes have resulted in small and isolated

109 populations, particularly within the sedentary boreal ecotype (COSEWIC, 2014). In Ontario, the

110 range of boreal caribou has been contracting northward for over a century, resulting in isolated

111 populations that have managed to persist along the coast and nearshore islands of Lake Superior,

112 over $150 \mathrm{~km}$ south of the continuous range edge (Ontario Ministry of Natural Resources, 2009;

113 Schaefer, 2003). Here, we analyze inbreeding in boreal caribou from Ontario where the range has

114 recently receded, in comparison to boreal caribou from the continuous range in Ontario and 
115 Manitoba, and other caribou ecotypes in central and eastern Canada, and western Greenland. We

116 included eastern migratory caribou from populations in Quebec and Ontario that have

117 experienced historic and recent declines (COSEWIC, 2017a), as well as barren-ground caribou

118 from a large population that has not experienced dramatic historic or recent declines (COSEWIC,

119 2016). We also included two individuals from western Greenland, where populations have

120 declined by up to $90 \%$ in the past two decades (Jepsen, Siegismund, \& Fredholm, 2002) despite

121 absence of major predators (Cuyler \& Østergaard, 2005). Previous research has indicated high

122 levels of inbreeding in the Greenland population we sampled (Jepsen et al., 2002; Taylor et al.,

123 2020).

Rapid declines in caribou range and population sizes have raised conservation concerns,

125 as small and isolated populations are more prone to inbreeding and eventually may fall into an

126 "extinction vortex" and become extirpated (Gagnon, Yannic, Perrier, \& Côté, 2019; Gilpin \&

127 Soule, 1986). Yet, it remains unclear how inbreeding is affecting caribou, and whether inbreeding

128 depression is a pertinent threat. A recent study correlated heterozygosity and fitness in two

129 rapidly declining eastern migratory caribou populations, and found no evidence of inbreeding

130 depression (Gagnon et al., 2019). However, the two eastern migratory populations studied by

131 Gagnon et al. (2019) have historically experienced dramatic fluctuations in population size

132 (COSEWIC, 2017a), which may have allowed for the purging of recessive deleterious alleles.

133 The effects of inbreeding depression can be resisted by selection preventing the unmasking of

134 deleterious recessive alleles or maintaining heterozygote advantage (Hedrick \& Garcia-Dorado,

135 2016). Balancing selection, specifically, negative-frequency dependent selection has recently

136 been associated with maintaining phenotypic polymorphisms in caribou along an environmental

137 gradient in western Canada (Cavedon et al. 2019), but has not been linked to inbreeding. 
We used whole genome sequences to investigate inbreeding in small and isolated populations of boreal caribou from southern Ontario, boreal caribou populations from the continuous caribou range of Ontario and Manitoba, eastern migratory caribou, barren-ground

141 caribou, and caribou from western Greenland (Figure 1). We sampled caribou from populations

142 that differed in evolutionary history, demographic history and extent of isolation. We predicted to

143 find a large proportion of genomic $\mathrm{ROH}$ in boreal caribou from the southern range of Ontario

144 (Figure 1), where recent range contraction has resulted in small and isolated populations (Drake

145 et al., 2018; Schaefer, 2003). We expected to detect lower levels of inbreeding, quantified as

$146 \mathrm{ROH}$, in boreal caribou from the continuous range of Ontario and Manitoba, as well as in the

147 eastern migratory caribou from Ontario and Quebec; populations that have experienced recent

148 declines but are not as small and isolated as the southern range of Ontario (COSEWIC, 2014a,

149 2017a). Further, we predicted barren-ground caribou from the Qamanirijuaq population ranging

150 over northern Manitoba and Nunavut (Figure 1) will have the lowest proportion of their genome

151 in $\mathrm{ROH}$, as they occur in large populations that have not experienced dramatic historical or recent

152 declines (COSEWIC, 2016). Continuous stretches of ROH are broken up by the recombination of

153 DNA through successive mating events (Ceballos, Joshi, Clark, Ramsay, \& Wilson, 2018); thus,

154 we expected to find the longest $\mathrm{ROH}$ in boreal caribou from the southern range of Ontario,

155 reflecting recent inbreeding caused by anthropogenic range contraction (Schaefer, 2003). Caribou

156 from western Greenland have likely experienced inbreeding over a longer period of time (Jepsen

157 et al., 2002); thus, we predicted a large proportion of their genome will be in short ROH. Finally,

158 we predicted to find genes associated with deleterious recessive alleles or heterozygote advantage

159 in regions where balancing selection has maintained islands of heterozygosity despite inbreeding

160 (Benazzo et al., 2017). 


\section{2| METHODS}

\section{1 | Caribou sampling}

Tissue samples of three boreal caribou were collected from the southern caribou range of

165 Ontario (two samples from Michipicoten Island, one from Pukaskwa National Park) by provincial biologists and sequenced for the study. Whole-genome raw reads from the continuous

167 caribou range of Ontario, Manitoba, Quebec, and Greenland (Taylor et al. 2020) were used for

168 the remaining populations and can be retrieved from the National Centre for Biotechnology

169 (NCBI) under the BioProject Accession no. PRJNA 634908.

We included four samples from south of the continuous boreal caribou range in Ontario:

171 two samples from the Michipicoten Island and one from the coastal range of Lake Superior

172 (Pukaskwa National Park), as well as one individual from where the continuous caribou range

173 has more recently contracted near Ignace, Ontario (Figure 1). The caribou population on

174 Michipicoten Island was established in the 1980s, when a single bull was sighted on the island 175 and eight additional caribou were translocated from the Slate Islands (Bergerud, Dalton, Butler,

176 Camps, \& Ferguson, 2007). The Michipicoten Island population steadily grew, and was estimated

177 to contain 680 caribou in 2011 (Kuchta, 2012); however an especially cold winter in 2014

178 resulted in ice corridors between the mainland and islands, allowing wolves to colonize the island

179 (Ontario Ministry of Natural Resources, 2018). The caribou population rapidly declined under

180 this new predation pressure, prompting the Government of Ontario to work with partners,

181 including Michipicoten First Nation, to translocate some of the few remaining caribou on

182 Michipicoten Island to other Lake Superior islands: the Slate Islands and Caribou Island (Ontario 
183 Ministry of Natural Resources, 2018). Over the past four decades, the coastal caribou population

184 in Pukaskwa National Park has steadily declined and become increasingly isolated from the

185 continuous caribou range of Ontario (Patterson et al., 2014). Caribou disappeared from the park

186 in 2011, and reappeared in 2015, perhaps due to colonization from one of the Lake Superior

187 islands. One of the last caribou captured on wildlife cameras deployed in Pukaskwa National

188 Park had small, malformed antlers, which was suggested to be a sign of inbreeding (Drake et al.,

189 2018). Currently, there are no caribou in the park and the population is considered potentially

190 extirpated.

We also selected one sample from Cochrane, Ontario, which falls along the southern edge

192 of the continuous boreal caribou range and two samples from the Naosap population in Manitoba,

193 which falls within the continuous range and in 2012 was estimated to contain 100-200 caribou

194 (COSEWIC, 2014a). We selected two barren-ground caribou samples from the Qamanirijuaq

195 population that ranges over northern Manitoba and Nunavut, a large population that was

196 estimated to contain 264,661 individuals in 2014 and has not experienced dramatic historical or

197 recent declines (COSEWIC, 2016). Within the eastern migratory ecotype, we included two

198 samples from the George River population, Quebec, which has experienced a dramatic

199 population decline over recent decades from approximately 823,000 individuals in 1993

200 (Couturier, Courtois, Crépeau, Rivest, \& Luttich, 1996), to approximately 8,900 individuals in

2012016 (Gagnon et al., 2019); our samples were obtained in 2008, after population declines had

202 already occurred. We also included two eastern migratory caribou from the Pen Island population

203 in northern Ontario, which was estimated to contain 16,638 individuals in 2011 (COSEWIC,

204 2017a). The eastern migratory caribou populations in Ontario and Quebec are geographically 
205 isolated from each other (Figure 1) and recent research has revealed a divergent evolutionary

206 history between these two populations (Taylor et al., 2020). Finally, we selected two samples

207 from the Kangerlussuaq area of western Greenland, where populations have declined by up to

$20890 \%$ in the past two decades (Jepsen et al., 2002). Caribou from this region are geographically

209 separated by the Maniitsoq glacier and have not hybridized with semi-domestic reindeer, unlike

210 some caribou from other regions in Greenland (Jepsen et al. 2002).

\section{2 | Genome sequencing, assembly, and quality control}

DNA was extracted from the tissue samples using the Qiagen DNeasy kit and following

using a Qubit system (Thermo Fisher Scientific, MA, USA) to ensure all samples were above the

then sent to The Centre for Applied Genomics (TCAG), at The Hospital for Sick Children

218 (Toronto, ON). An Illumina library prep kit (Illumina, San Diego, CA, USA) was used to

219 fragment the DNA and apply sequencing adapters. Each sample was sequenced on one lane of

220 the Illumina HiSeqX platform, yielding paired-end 150bp sequence reads. The raw reads of most

221 samples $(\mathrm{N}=12)$ are already available at the National Centre for Biotechnology (NCBI) under the

222 BioProject Accession no. PRJNA 634908. The raw reads of the remaining individuals (N=3) will

223 be made available by time of publication.

We conducted all bioinformatic analyses using cloud computing resources from Compute

225 Canada (RRG gme-665-ab) and Amazon Web Services (https://aws.amazon.com/). First, we

226 removed sequencing adapters and low-quality bases (phred score <30) from the samples using

227 CutAdapt (Martin, 2011) in the program TrimGalore 0.4.2 (Krueger, 2012). We mapped the 
228 sequenced reads to the caribou reference genome (Taylor et al., 2019) using Bowtie2 2.3.0

229 (Langmead \& Salzberg, 2012). We used Samtools 1.5 (Li et al., 2009) to convert the SAM file to

230 a BAM file. We then removed duplicate reads and added read group information to each BAM

231 file with Picard 2.17.3 (Broad Institute, n.d.). We sorted the BAM file with Samtools 1.5 and

232 built an index with Picard 2.17.3. Finally, we checked the quality of each BAM file using FastQC

2330.11 .8 (Andrews, 2010) and calculated the average depth of coverage in ROHan (Renaud,

234 Hanghoj, Korneliussen, Willerslev, \& Orland, 2019). All samples (N=15) passed the FASTQC

235 quality assessments and had a high depth of coverage (28-36x; Table 1).

236

We used the GATK 3.8 (McKenna et al., 2010) Haplotype Caller to produce a variant call

237 format (VCF) file for each caribou. We further used GATK 3.8 to combine and genotype the

238 GVCFs, producing one joint VCF for all samples. We then used VCFtools 0.1.14 (Danecek et al.,

239 2011) to perform additional filtering. We removed indels, sites with a depth $<10$ or $>80$, and low-

240 quality genotype calls (score <20). We also filtered to remove genotypes with more than $10 \%$

241 missing data. We did not filter to remove any SNP with a minor allele frequency (MAF) of less

242 than 0.05 as we have only one or two individuals from each location, and thus did not want to

243 remove private sites. The combined VCF file with all caribou contained 28246751 SNPs.

\section{$244 \quad 2.3 \mid$ Inbreeding analyses}

With the combined VCF file, we used VCFtools 0.1.14 (Danecek et al., 2011) to calculate transition/transversion ratio. 
251 Bayesian approach to identify ROH with a Hidden Markov Model (HMM). For all ROHan

252 analyses we used a sliding window size of 50kb, allowed a maximum heterozygosity level of

2530.0005 within $\mathrm{ROH}$, and specified a transition/transversion ratio of 1.97428 , based on our

254 calculation from a VCF file that contained all individuals.

ROHan produced a file of heterozygosity estimates for every $50 \mathrm{~kb}$ window across the

256 genome, as well as a file with the location and length of each $\mathrm{ROH}$. We then plotted the

257 heterozygosity estimates and ROHs across scaffolds of interest to compare patterns between

258 individuals using ggplot2 in R (Wickham, 2016). Namely, from the 40 largest scaffolds,

259 representing approximately $43 \%$ of the caribou reference genome, we selected scaffolds where

260 the lower local heterozygosity estimate $(\theta)$ exceeded 0.02 (Table S2). We excluded elevated

261 heterozygosity estimates that were located on the edges of scaffolds, as they may be due to

262 sequence error. Within populations where inbreeding was detected $\left(\mathrm{F}_{\mathrm{ROH}}>0.1000\right)$, we also

263 calculated how many ROH are identical by descent (IBD) or unique using the intersect function

264 in BEDtools (Quinlan \& Hall, 2010).

265 We then conducted BLAST searches across regions of elevated heterozygosity to identify

266 genes that have maintained heterozygosity despite inbreeding. We used NCBI's nucleotide

267 MegaBLAST algorithm (Agarwala et al., 2016) and masked for lower case letters, as our

268 reference genome contains both hard and soft masking (Taylor et al., 2019). All other BLAST

269 settings were default.

\section{$271 \quad 3$ | RESULTS}

\section{$272 \quad 3.1 \mid$ Inbreeding estimates}


274 grouped VCF file was highly correlated with genome-wide heterozygosity $(\theta)$ and the proportion

275 of the genome in $\mathrm{ROH}\left(\mathrm{F}_{\mathrm{ROH}}\right)$, which were both calculated in ROHan (Renaud et al., 2019) from

276 individual BAM files (Figure S2).

$278=0.3373,0.5017$ ), with ROH comprising half of the genome of one of the individuals (Figure 1).

$279 \mathrm{~F}_{\mathrm{ROH}}$ values were also elevated in boreal caribou from Ignace, Ontario that have recently become 280 isolated from the continuous caribou range due to northward range contraction $\left(\mathrm{F}_{\mathrm{ROH}}=0.2398\right)$,

281 as well as in boreal caribou from Lake Superior (Pukaskwa National Park and Michipicoten

282 Island) that are located over $150 \mathrm{~km}$ south of the continuous range edge $\left(\mathrm{F}_{\mathrm{ROH}}=0.1000-0.1902\right.$;

283 Figure 1). The remaining individuals had $\mathrm{F}_{\mathrm{ROH}}$ values between 0.0123 and 0.0963 , with the two

284 notably lowest values corresponding to barren-ground caribou (Table 1).

285 We investigated the average length of $\mathrm{ROH}$ across each genome to estimate whether

286 inbreeding occurred recently or historically; the two individuals with the longest average $\mathrm{ROH}$

287 were observed in populations located south of the continuous caribou range in Ontario (Ignace

288 and Michipicoten Island). Caribou from western Greenland also had long ROH, although they

289 were shorter than predicted based on $\mathrm{F}_{\mathrm{ROH}}$ (Figure 2).

290

2913.2 | Identical by descent ROH

292 We calculated relatedness between all individuals ( $\varphi$; Table S1), as well as how many

$293 \mathrm{ROH}$ were identical by descent (IBD) for populations where $\mathrm{F}_{\mathrm{ROH}}$ was greater than 0.10 (Table 1)

294 to gain further insights into their inbreeding histories. 
$\mathrm{S} 1)$. The boreal caribou with the highest inbreeding estimate $\left(\mathrm{F}_{\mathrm{ROH}}=0.23\right)$ was from Ignace,

showed no evidence of relatedness to Michipicoten caribou (Table S1). The caribou from (Table 1). estimate $(\varphi)$ between these two individuals was 0.09 , corresponding to $2^{\text {nd }}$ degree $(\varphi=0.125)$ or $3^{\text {rd }}$ degree relatives $(\varphi=0.0625)$, which would increase the proportion of the genome that is IBD.

314 The two caribou from western Greenland shared low relatedness values with all of the Canadian caribou (Table S1).

\section{3 | Islands of heterozygosity}


We found multiple regions across the genome where high heterozygosity was maintained across all populations, even in individuals that have experienced high levels of inbreeding. In the scaffolds that had a peak of heterozygosity exceeding 0.02 (Table S2). Caribou from western

322 Greenland had many segments of $\mathrm{ROH}$, and boreal caribou from the southern discontinuous 323 range of Ontario had notably long, continuous segments; however, we found breaks in the ROH 324 when plotted across these regions of elevated heterozygosity (Figure 3). Using BLAST

325 (Agarwala et al., 2016), we were able to detect functional genes within eight of these islands of heterozygosity with various functions including signaling regulation, nucleotide binding, and the

327 regulation of feeding behaviour. Several of the genes we identified have functions associated

328 with immunity (Figure 3A-D), including: tyrosine kinase (TxK), a member of the PRAME

329 family, and an immunoglobulin superfamily member (IgSF10). An island of heterozygosity on

330 Scaffold 2797 (Figure 3D) contains prolactin (PRL), a gene best known for its role in

331 reproduction, which has also been associated with immunity (Borba, Zandman-Goddard, \&

332 Shoenfeld, 2018). Some of the genes we detected have known polymorphisms, such as UDP-

333 Glucuronosyltransferase (UGT) on Scaffold 3054 (Figure 3E), which functions in the elimination

334 of toxins (Miners, McKinnon, \& Mackenzie, 2002). We also found heterozygosity had been

335 maintained within a region on Scaffold 3761 (Figure 3F) that was identified as Ankyrin Repeat

336 Domain 26 (ANKRD26), a gene associated with feeding behaviour (Bera et al., 2008). When the

337 caribou scaffolds are aligned to the bovine genome (National Center for Biotechnology

338 Information, 2016), the scaffolds map to the respective bovine chromosomes that include each of 339 these genes, validating our findings. 


\section{4 | DISCUSSION}

We analyzed high-coverage whole genomes to investigate inbreeding extent in caribou

343 from divergent populations in Canada and Greenland. We quantified ROH in high-coverage

344 whole genomes of boreal caribou from small, isolated populations in the southern caribou range

345 of Ontario, Canada, in comparison to caribou from the continuous range of Ontario, other caribou

346 ecotypes in Canada, and western Greenland; populations presenting divergent evolutionary

347 histories, differing in population size and extent of isolation. As predicted, we found boreal

348 caribou from the southern range of Ontario had a relatively high proportion of their genomes in

$349 \mathrm{ROH}\left(\mathrm{F}_{\mathrm{ROH}}=0.1000,0.2398\right)$, where recent range contraction has resulted in small and isolated

350 populations (Figure 1). We also observed the longest average $\mathrm{ROH}$ in this region, namely in

351 boreal caribou from Michipicoten Island, and Ignace Ontario, confirming their inbreeding

352 occurred recently. Conversely, we found the lowest levels of inbreeding in barren-ground caribou

353 from the Qamanirijuaq population in Manitoba, which was predicted as this large population has

354 not experienced dramatic historic or recent declines (COSEWIC, 2016). All of the other

355 Canadian caribou populations investigated had relatively low levels of inbreeding (Table 1). We

356 examined two caribou from the Kangerlussuaq population in western Greenland, as previous

357 research has indicated inbreeding in this population (Jepsen et al., 2002; Taylor et al., 2020), and

358 found an extremely high proportion of $\mathrm{ROH}\left(\mathrm{F}_{\mathrm{ROH}}=0.3373,0.5017\right)$. Their genomes were

359 comprised of some long ROH, although they were shorter than expected based on $\mathrm{F}_{\mathrm{ROH}}$ (Figure

360 2), indicating their inbreeding has occurred over a longer period of time than that of other

361 populations, as we predicted. Finally, we predicted that we would find genes associated with

362 deleterious recessive alleles or heterozygote advantage within regions where balancing selection 
363 has maintained islands of heterozygosity despite inbreeding. We detected islands of

364 heterozygosity on 18 of the 40 scaffolds examined and found breaks in the ROH when plotted

365 across the islands. We identified functional genes within several of the islands that are associated

366 with various functions, including immunity, the elimination of toxins, and a deleterious recessive

367 condition associated with the regulation of feeding behaviour.

\section{1 | Inbreeding histories}

370 We observed the lowest inbreeding estimates in barren-ground caribou from the

371 Qamanirijuaq population in Manitoba. These caribou occur in large populations on the tundra and

372 previous research has indicated the barren-ground caribou included in this study have admixed

373 with other caribou ecotypes (Taylor et al., 2020), which was reflected by their low inbreeding

374 estimates; in fact, the only negative inbreeding coefficients $(F)$ observed were in barren-ground

375 caribou from the Qamanirijuaq population, indicating outbreeding has occurred.

376 We found the highest prevalence of genomic inbreeding in caribou from western Greenland,

377 whose genomes were 0.3373 and 0.5017 in ROH. Although extreme, these results are

378 comparable to the uppermost ROH estimates of other studies; for example, inbred Scandinavian-

379 born wolves have up to 0.54 of their genome in ROH (Kardos et al., 2018). The two individuals

380 from western Greenland also shared a large proportion of those ROH that were IBD (92\%). This

381 is notably higher than other values in the literature. For example, a recent study of pumas

382 reported a maximum of $36 \%$ IBD between two individuals who had similar inbreeding estimates

383 as the western Greenland caribou $\left(\mathrm{F}_{\mathrm{ROH}}=0.5-0.6\right)$. However, our results also show that the two

384 caribou from Greenland were $2^{\text {nd }}$ or $3^{\text {rd }}$ degree relatives, which elevates the proportion of the

385 genome that is shared, or IBD. 
In recent decades, native caribou of western Greenland have experienced population reductions of up to $90 \%$ (Jepsen et al., 2002). A microsatellite study of several caribou regions in western Greenland investigated the region included in our study, near Kangerlussuaq, and found high inbreeding coefficients at two of five loci investigated (Region 1; Jepsen et al., 2002).

391 loci investigated, unlike another isolated region that had lost several polymorphisms (Jepsen et al.

392 2002). Our analysis of whole genome sequences echoes this finding, as we find islands of

393 heterozygosity maintained within several genes, despite extremely high inbreeding estimates

$394\left(\mathrm{~F}_{\mathrm{ROH}}=0.3373,0.5017\right)$. The high heterozygosity within these genes suggests they may be under

395 balancing selection; thus, loss of heterozygosity at these loci may result in lowered fitness, or

396 inbreeding depression. Although we also observed long ROH in caribou from western Greenland,

397 they were shorter than predicted based on $\mathrm{F}_{\mathrm{ROH}}$, suggesting inbreeding occurred more historically

398 in western Greenland than it has in the other inbred populations investigated. Our results indicate 399 western Greenland caribou have undergone inbreeding over a longer time scale, which may have 400 allowed for the purging of deleterious alleles. The maintenance of islands of heterozygosity 401 within ROH suggests that inbred caribou may have enough genomic variation to avoid the fitness consequences of inbreeding depression. Indeed, despite our finding that caribou from the

403 Kangerlussuaq region of western Greenland are extremely inbred, previous studies have found 404 this population and the neighbouring population in Akia have notably high fertility, and are two 405 of the only caribou populations in the world where twinning has been observed (Cuyler \& 406 Østergaard, 2005). We examined the lengths of $\mathrm{ROH}$ to estimate if inbreeding occurred recently, resulting in 
were observed near the current southern edge of the boreal caribou range in Ignace, Ontario,

410 suggesting recent isolation caused by range contraction. This result is congruent with the findings

411 of a microsatellite study that suggested recent genetic erosion, a decrease in connectivity, and an

412 increase in inbreeding along the southern continuous range edge of boreal caribou in Ontario and

413 Manitoba (Thompson, Klütsch, Manseau, \& Wilson, 2019). The second longest average ROH

414 was observed on Michipicoten Island, Ontario, an isolated population that has experienced

415 several recent bottlenecks (Bergerud et al., 2007; Fletcher, 2017). We also found the two caribou

416 sampled from Michipicoten Island were related to each other but were not related to a caribou

417 from the nearby coastal range in Pukaskwa National Park (Table S1). Notably, the caribou from

418 Cochrane has undergone less inbreeding than the other Ontario boreal caribou sampled and had

419 the least IBD ROH with the Michipicoten Island caribou. Previous research based on

420 microsatellite data suggested Michipicoten Island and Pukaskwa National Park belong to a

421 different genetic cluster than the nearby boreal caribou from Cochrane (Drake et al., 2018).

422 Additionally, a recent genomic study found that boreal caribou from Cochrane, Ontario are

423 genetically more similar to eastern migratory caribou from Quebec than they are to boreal

424 caribou from Ignace, Ontario (Taylor et al., 2020), providing further evidence that there may be

425 divergent evolutionary histories between these populations.

Despite vastly different inbreeding histories among populations, we found regions of high

429 heterozygosity that were maintained across all individuals, regardless of population size or

430 ecotype. We identified functional genes within each of these peaks, with various functions

431 including signaling regulation, nucleotide binding, and the elimination of toxins. Several of the 
432 genes we identified are associated with immunity, such as prolactin (PRL), which has been linked

433 to both reproduction and immunity (Borba et al., 2018), and tyrosine kinase (TxK), which plays a

434 role in T-cell development (Sommers et al., 1999). Benazzo et al. (2017) found similar evidence

435 of balancing selection for genes associated with immune and olfactory systems, where non-

436 random peaks of variation were maintained despite extreme inbreeding in endangered brown

437 bears. We also found a gene that may have maintained variation due to the presence of a

438 deleterious recessive allele. We found high heterozygosity within a region that contains

439 ANKRD26, a gene associated with the regulation of feeding behaviour. Previous research has

440 demonstrated homozygosity at this gene results in metabolic defects in mammals, including

441 increased obesity and insulin resistance (Bera et al., 2008).

442 In a recent study of two eastern migratory caribou populations, correlations between

443 heterozygosity and fitness (HFCs) found no evidence of inbreeding depression (Gagnon et al.,

444 2019). Notably, eastern migratory caribou from one of these population were also included in our

445 study and had relatively low inbreeding estimates $\left(\mathrm{F}_{\mathrm{ROH}}=0.05-0.07\right)$. The inbreeding levels in

446 that population may be too low to trigger inbreeding depression, but it is also possible that the

447 effects of inbreeding depression have been resisted by selection. Balancing selection can prevent

448 the unmasking of deleterious recessive alleles or maintain heterozygote advantage thereby

449 preventing the expression of inbreeding depression (Hedrick \& Garcia-Dorado, 2016). In this

450 study, we found islands of heterozygosity at specific gene regions across populations differing in

451 population size and extent of isolation. This result suggests that strong balancing selection could

452 be maintaining heterozygosity even in the face of extreme inbreeding. Balancing selection,

453 specifically negative-frequency dependent selection, has also recently been suggested to be a 
454 mechanism maintaining phenotypic polymorphisms in caribou along an environmental gradient

455 in western Canada (Cavedon et al., 2019).

\section{$457 \quad 4.3 \mid$ Conclusions}

We used runs of homozygosity $(\mathrm{ROH})$ to quantify inbreeding in caribou from populations

459 representing divergent evolutionary histories, differing in population size and extent of isolation.

460 We explored the extent of inbreeding and the maintenance of genomic variation in high-coverage

461 whole genomes of boreal caribou from small, isolated populations in the southern caribou range

462 of Ontario, Canada, in comparison to caribou from the continuous range of Ontario, other caribou

463 ecotypes in Canada, and western Greenland. We found divergent demographic histories among

464 populations, particularly within the boreal ecotype, where we found low levels of inbreeding in

465 caribou from the continuous boreal range, and elevated inbreeding estimates in populations that

466 have become isolated due to recent range contraction. We also observed the longest average $\mathrm{ROH}$

467 in these isolated boreal caribou populations, confirming their inbreeding occurred recently. We

468 observed the greatest amounts of inbreeding in caribou from western Greenland, whose genomes

469 were approximately a third to a half in $\mathrm{ROH}$; although their $\mathrm{ROH}$ were shorter than expected,

470 implying inbreeding has occurred over a longer time in western Greenland than it has in Ontario.

471 Across populations with divergent demographic histories, we infer the maintenance of

472 variation within genes associated with various functions, including immunity, the removal of

473 toxins, and a deleterious recessive condition, suggesting balancing selection is occurring despite

474 extreme inbreeding. The maintenance of heterozygosity in these key regions may help resist the

475 effects of inbreeding depression. To further investigate how inbreeding depression may be

476 affecting these populations, researchers should examine beyond the islands of heterozygosity and 
477 attempt to identify genes located within $\mathrm{ROH}$, especially those that are likely to be associated 478 with heterozygote advantage or a deleterious recessive allele.

\section{ACKNOWLEDGEMENTS}

Funding was provided through an NSERC Collaborative Research \& Development (CRD) grant

to P.J.W., NSERC CREATE and Discovery grants to J.B. and P.J.W., and a Garfield Weston

484 Foundation Fellowship to K.S., Ontario Graduate Scholarships, and Ontario Species at Risk

485 Stewardship Program funding to K.S. The results reported are reflective of the independent

486 analyses conducted for this study and do not necessarily reflect the views of the Government of

487 Ontario. We are grateful to Dr. Art Rodgers for his assistance with sample collection and advice

488 on this paper. We thank Bridget Redquest and Austin Thompson for extracting DNA, and The

489 Centre for Applied Genomics (TCAG) at the Hospital for Sick Children (Toronto, Ontario) for

490 library preparation and sequencing. We also acknowledge the facilities of the Shared Hierarchical

491 Academic Research Computing Network (SHARCNET: www.sharcnet.ca) and Compute

492 Canada/ Calcul Canada gme-665-ab.Compute Canada (RRG gme-665-ab), and Amazon Cloud

493 Computing for high-performance computing services. We are grateful for the efforts of those

494 who provided tissue samples including the Government of Manitoba, Government of

495 Ontario, Government of Greenland, and Environment and Climate Change Canada. 


\section{REFERENCES}

500

501

502

503

504

505

506

507

508

509

510

511

512

513

514

515

516

Agarwala, R., Barrett, T., Beck, J., Benson, D. A., Bollin, C., Bolton, E., ... Zbicz, K. (2016). Database resources of the National Center for Biotechnology Information. Nucleic Acids Research, 44(D1), D7-D19. doi: 10.1093/nar/gkv1290

Benazzo, A., Trucchi, E., Cahill, J. A., Maisano Delser, P., Mona, S., Fumagalli, M., ... Bertorelle, G. (2017). Survival and divergence in a small group: The extraordinary genomic history of the endangered Apennine brown bear stragglers. Proceedings of the National Academy of Sciences, 114(45), 1-9. doi: 10.1073/pnas.1707279114

Bera, T. K., Liu, X. F., Yamada, M., Gavrilova, O., Mezey, E., Tessarollo, L., ... Pastan, I. (2008). A model for obesity and gigantism due to disruption of the Ankrd26 gene. Proceedings of the National Academy of Sciences of the United States of America, 105(1), 270-275. doi: 10.1073/pnas.0710978105

Bergerud, A. T., Dalton, W. J., Butler, H., Camps, L., \& Ferguson, R. (2007). Woodland caribou persistence and extirpation in relic populations on Lake Superior. Rangifer, 27(17), 57-78.

Borba, V. V., Zandman-Goddard, G., \& Shoenfeld, Y. (2018). Prolactin and autoimmunity. Frontiers in Immunology, 9(FEB), 1-8. doi: 10.3389/fimmu.2018.00073

Broad Institute. (n.d.). Picard. Retrieved from http://broadinstitute.github.io/picard

Cavedon, M., Gubili, C., Heppenheimer, E., vonHoldt, B., Mariani, S., Hebblewhite, M., ... Musiani, M. (2019). Genomics, environment and balancing selection in behaviourally bimodal populations: The caribou case. Molecular Ecology, 28(8), 1946-1963. doi: 10.1111/mec.15039

Ceballos, F. C., Joshi, P. K., Clark, D. W., Ramsay, M., \& Wilson, J. F. (2018). Runs of homozygosity: Windows into population history and trait architecture. Nature Reviews Genetics, 19(4), 220-234. doi: 10.1038/nrg.2017.109

Charlesworth, D., \& Willis, J. H. (2009). The genetics of inbreeding depression. Nature Reviews Genetics, 10, 783-796.

COSEWIC. (2011). Designatable Units for Caribou (Rangifer tarandus) in Canada. 88pp.

Retrieved from http://www.cosewic.gc.ca/eng/sct12/COSEWIC_Caribou_DU_Report_23Dec2011.pdf

COSEWIC. (2014a). COSEWIC assessment and status report on the Caribou Rangifer tarandus, Newfoundland population, Atlantic-Gaspésie population and Boreal population, in Canada. Ottawa: Committee on the Status of Endangered Wildlife in Canada. Retrieved from Committee on the Status of Endangered Wildlife in Canada website: www.registrelepsararegistry.gc.ca/default_e.cfm

COSEWIC. (2014b). COSEWIC assessment and Status Report on the Caribou Rangifer tarandus, Northern Mountain Population, Central Mounatin Population and Southern Mountain Population in Canada. Retrieved from http://www.sararegistry.gc.ca/virtual_sara/files/cosewic/sr_Caribou_Northern_Central_Sout hern_2014_e.pdf

COSEWIC. (2015). COSEWIC Assessment and Status Report on the Peary Caribou Rangifer tarandus pearyi in Canada. In Species at Risk Public Registry.

COSEWIC. (2016). COSEWIC assessment and status report on the caribou Rangifer tarandus, barren-ground population, in Canada. In Committee on the Status of Endangered Wildlife in 
Canada. Retrieved from http://www.registrelep-

sararegistry.gc.ca/default.asp?lang=en \&n=24F7211B-1

COSEWIC. (2017a). COSEWIC assessment and status report on the caribou Rangifer tarandus, Eastern Migratory population and Torngat Mountains population, in Canada. In Committee on the Status of Endangered Wildlife in Canada. Retrieved from http://www.registrelepsararegistry.gc.ca/default.asp?lang=en $\& n=24 F 7211 \mathrm{~B}-1$

COSEWIC. (2017b). COSEWIC Assessment and Status Report on the Caribou Rangifer tarandus Dolphin and Union population in Canada. In Committee on the Status of Endangered Wildlife in Canada. Retrieved from https://wildlife-species.canada.ca/species-riskregistry/virtual_sara/files/cosewic/srCaribouDolphinUnion2017e1.pdf

Couturier, S., Courtois, R., Crépeau, H., Rivest, L.-P., \& Luttich, S. (1996). Calving photocensus of the Rivière George Caribou Herd and comparison with an independent census. Rangifer, 16(4), 283. doi: 10.7557/2.16.4.1268

Cuyler, C., \& Østergaard, J. B. (2005). Fertility in two West Greenland caribou Rangifer tarandus groenlandicus populations during 1996/97: Potential for rapid growth. Wildlife Biology, 11(3), 221-227. doi: 10.2981/0909-6396(2005)11[221:FITWGC]2.0.CO;2

Danecek, P., Auton, A., Abecasis, G., Albers, C. A., Banks, E., DePristo, M. A., ... Durbin, R. (2011). The variant call format and VCFtools. Bioinformatics, 27(15), 2156-2158. doi: 10.1093/bioinformatics/btr330

Drake, C. C., Manseau, M., Klütsch, C. F. C., Priadka, P., Wilson, P. J., Kingston, S., \& Carr, N. (2018). Does connectivity exist for remnant boreal caribou (Rangifer tarandus caribou) along the Lake Superior Coastal Range? Options for landscape restoration. Rangifer, 38(1), 13. doi: $10.7557 / 2.38 .1 .4124$

Festa-Bianchet, M., Ray, J. C., Boutin, S., Côté, S. D., \& Gunn, A. (2011). Conservation of caribou (Rangifer tarandus) in Canada: an uncertain future. Canadian Journal of Zoology, 89(5), 419-434. doi: 10.1139/z11-025

Fletcher, R. (2017, November 14). Wolf, caribou issue on Michipicoten Island raises red flags for many. Sault Star. Retrieved from http://www.saultstar.com/2017/11/13/wolf-caribou-issueon-michipicoten-island-raises-red-flags-for-many

Gagnon, M., Yannic, G., Perrier, C., \& Côté, S. D. (2019). No evidence of inbreeding depression in fast declining herds of migratory caribou. Journal of Evolutionary Biology, (August), 114. doi: $10.1111 /$ jeb.13533

Gilpin, M. E., \& Soule, M. E. (1986). Minimum viable populations: processes of extinction. In M. . Soule (Ed.), Conservation Biology: The Science of Scarcity and Diversity (pp. 19-34). Sunderland, MA: Sinauer Associates.

Hammerly, S., Morrow, M. E., \& Johnson, J. A. (2013). A comparison of pedigree- and DNAbased measures for identifying inbreeding depression in the critically endangered Attwater's Prairie-chicken. Molecular Ecology, 22, 5313-5328. doi: 10.1111/mec.12482

Hedrick, P. W., \& Garcia-Dorado, A. (2016). Understanding Inbreeding Depression, Purging, and Genetic Rescue. Trends in Ecology and Evolution, 31(12), 940-952. doi: 10.1016/j.tree.2016.09.005

Herfindal, I., Haanes, H., Røed, K. H., Solberg, E. J., Markussen, S. S., Heim, M., \& Sæther, B.E. (2014). Population properties affect inbreeding avoidance in moose. Biology Letters, 10(12), 20140786-20140786. doi: 10.1098/rsbl.2014.0786

Jepsen, B. I., Siegismund, H. R., \& Fredholm, M. (2002). Population genetics of the native 
caribou (Rangifer tarandus groenlandicus) and the semi-domestic reindeer (Rangifer tarandus tarandus) in Southwestern Greenland: Evidence of introgression. Conservation Genetics, 3(4), 401-409. doi: 10.1023/A:1020523303815

Kardos, M., Åkesson, M., Fountain, T., Flagstad, Ø., Liberg, O., Olason, P., ... Ellegren, H. (2018). Genomic consequences of intensive inbreeding in an isolated wolf population. Nature Ecology \& Evolution, (2), 124-131. doi: 10.1038/s41559-017-0375-4

Kardos, M., Luikart, G., \& Allendorf, F. W. (2015). Measuring individual inbreeding in the age of genomics: marker-based measures are better than pedigrees. Heredity, 115(1), 63-72. doi: 10.1038/hdy.2015.17

Krueger, F. (2012). Trim Galore! Retrieved from https://www.bioinformatics.babraham.ac.uk/projects/trim_galore/

Kuchta, B. (2012). Bottom-up and Top-down Forces Shaping Caribou Forage Availability on the Lake Superior Coast. Lakehead University.

Laliberte, A. S., \& Ripple, W. J. (2004). Range Contractions of North American Carnivores and Ungulates. BioScience, 54(2), 123. doi: 10.1641/00063568(2004)054[0123:RCONAC]2.0.CO;2

Langmead, B., \& Salzberg, S. L. (2012). Fast gapped-read alignment with Bowtie 2. Nature Methods, 9, 357-359.

Manichaikul, A., Mychaleckyj, J. C., Rich, S. S., Daly, K., Sale, M., \& Chen, W. M. (2010). Robust relationship inference in genome-wide association studies. Bioinformatics, 26(22), 2867-2873. doi: 10.1093/bioinformatics/btq559

Martin, M. (2011). Cutadapt removes adapter sequences from high-throughput sequencing reads. EMBnet.Journal, 17, 10-12.

Miners, J. O., McKinnon, R. A., \& Mackenzie, P. I. (2002). Genetic polymorphisms of UDPglucuronosyltransferases and their functional significance. Toxicology, 181-182, 453-456. doi: 10.1016/S0300-483X(02)00449-3

National Center for Biotechnology Information. (2016). Genome Assembly and Annotation report Bos taurus (cattle). Retrieved November 29, 2020, from NCBI website: https://www.ncbi.nlm.nih.gov/genome/82

Ontario Ministry of Natural Resources. (2009). Ontario's Woodland Caribou Conservation Plan. $28 \mathrm{pp}$.

Ontario Ministry of Natural Resources. (2018). Seeking Advice on the Future of Caribou in the Lake Superior Coast Range. Retrieved from http://www.ecolog.com/daily_images/1004158029-1004159610.pdf

Palkopoulou, E., Mallick, S., Skoglund, P., Enk, J., Rohland, N., Li, H., ... Dalén, L. (2015). Complete genomes reveal signatures of demographic and genetic declines in the woolly mammoth. Current Biology, 25(10), 1395-1400. doi: 10.1016/j.cub.2015.04.007

Polfus, J. L., Manseau, M., Simmons, D., Neyelle, M., Bayha, W., Andrew, F., \& Andrew, L. (2016). Łegha' Gots' Enete ( Learning Together ): the Importance of Indigenous. In Ecology and Society (Vol. 21). doi: 10.5751/ES-08284-210218

Quinlan, A. R., \& Hall, I. M. (2010). BEDTools: A flexible suite of utilities for comparing genomic features. Bioinformatics, 26(6), 841-842. doi: 10.1093/bioinformatics/btq033

Renaud, G., Hanghoj, K., Korneliussen, T. S., Willerslev, E., \& Orland, L. (2019). Joint Estimates of Heterozygosity and Runs of Homozygosity for Modern and Ancient Samples. Genetics, 212(July), 587-614. 
Saremi, N. F., Supple, M. A., Byrne, A., Cahill, J. A., Coutinho, L. L., Dalén, L., ... Shapiro, B. (2019). Puma genomes from North and South America provide insights into the genomic consequences of inbreeding. Nature Communications, 10(1). doi: 10.1038/s41467-01912741-1

Schaefer, J. A. (2003). Long-Term Range Recession and the Persistence of Caribou in the Taiga. Conservation Biology, 17(5), 1435-1439. doi: 10.1046/j.1523-1739.2003.02288.x

Sommers, C. L., Rabin, R. L., Grinberg, A., Tsay, H. C., Farber, J., \& Love, P. E. (1999). A role for the Tec family tyrosine kinase Txk in T cell activation and thymocyte selection. Journal of Experimental Medicine, 190(10), 1427-1438. doi: 10.1084/jem.190.10.1427

Szpiech, Z. A., Xu, J., Pemberton, T. J., Peng, W., Zöllner, S., Rosenberg, N. A., \& Li, J. Z. (2013). Long runs of homozygosity are enriched for deleterious variation. American Journal of Human Genetics, 93(1), 90-102. doi: 10.1016/j.ajhg.2013.05.003

Taylor, R. S., Horn, R. L., Zhang, X., Brian Golding, G., Manseau, M., \& Wilson, P. J. (2019). The Caribou (Rangifer tarandus) genome. Genes, 10(7), 4-9. doi: 10.3390/genes10070540

Taylor, R. S., Manseau, M., Horn, R. L., Keobouasone, S., Golding, G. B., \& Wilson, P. J. (2020). The role of introgression and ecotypic parallelism in delineating intra-specific conservation units. Molecular Ecology, (00), 1-17. doi: 10.1111/mec.15522

Thompson, L. M., Klütsch, C. F. C., Manseau, M., \& Wilson, P. J. (2019). Spatial differences in genetic diversity and northward migration suggest genetic erosion along the boreal caribou southern range limit and continued range retraction. Ecology and Evolution, (April), ece3.5269. doi: 10.1002/ece3.5269

Wickham, H. (2016). ggplot2: Elegant Graphics for Data Analysis. New York.: Springer-Verlag. Retrieved from https://ggplot2.tidyverse.org 


\section{DATA ACCESSIBILITY}

659 The raw reads of 12 individuals are available at the National Centre for Biotechnology (NCBI)

660 under the BioProject Accession no. PRJNA 634908. The raw reads of the remaining three

661 individuals will be made available by time of publication.

663 AUTHOR CONTRIBUTIONS

664 K.S., J.B., P.J.W., and M.M. conceived and designed the study. J.B., P.J.W., and M.M. oversaw

665 the research as Co-Principal Investigators. K.S. and S.K. performed bioinformatic analyses with

666 guidance from R.S.T. and R.L.H. K.S. wrote the manuscript and J.B., R.S.T, M.M., and P.J.W.

667 provided feedback and edited the manuscript.

668

669 


\section{Tables}

671 Table 1. Information for each caribou included in this study: sampling locations and individual

672 reference number, subspecies classification and Canadian designatable units, population size and

673 extent of isolation, mean depth of coverage from whole genome mapped BAM files, and

674 inbreeding estimates.

\begin{tabular}{|c|c|c|c|c|c|c|c|c|}
\hline $\begin{array}{l}\text { Location and } \\
\text { Reference } \\
\text { Number }\end{array}$ & Subspecies & $\begin{array}{c}\text { Designatable } \\
\text { Unit }\end{array}$ & $\begin{array}{l}\text { Population } \\
\text { Size }\end{array}$ & $\begin{array}{l}\text { Extent } \\
\text { of } \\
\text { Isolation }\end{array}$ & $\begin{array}{l}\text { Mean } \\
\text { Depth }\end{array}$ & $\begin{array}{l}\text { Inbreeding } \\
\text { Coefficient } \\
\text { (F) }\end{array}$ & $\mathbf{F}_{\text {ROH }}$ & $\begin{array}{c}\text { Mean } \\
\text { Length } \\
\text { ROH }\end{array}$ \\
\hline $\begin{array}{c}\text { Ontario } \\
\text { Michipicoten } \\
\text { Island } \\
39650\end{array}$ & R. t. caribou & Boreal & Small & High & 33.6775 & 0.2167 & 0.1664 & 453134 \\
\hline $\begin{array}{c}\text { Ontario } \\
\text { Michipicoten } \\
\text { Island } 39651\end{array}$ & R. t. caribou & Boreal & Small & High & 35.9172 & 0.2092 & 0.1000 & 301072 \\
\hline $\begin{array}{c}\text { Ontario } \\
\text { Pukaskwa } \\
\text { National Park } \\
39653\end{array}$ & R. t. caribou & Boreal & Small & High & 36.3265 & 0.3897 & 0.1902 & 276247 \\
\hline $\begin{array}{c}\text { Ontario } \\
\text { Cochrane } \\
39654\end{array}$ & R. t. caribou & Boreal & Small & Low & 36.4583 & 0.0656 & 0.0403 & 173556 \\
\hline $\begin{array}{l}\text { Ontario } \\
\text { Ignace }\end{array}$ & R.t. caribou & Boreal & Small & Moderate & 28.0951 & 0.2398 & 0.2310 & 556507 \\
\hline 39590 & & & & & & & & \\
\hline $\begin{array}{c}\text { Manitoba } \\
\text { (The Pas) } \\
\text { Naosap herd } \\
35324\end{array}$ & R. t. caribou & Boreal & Small & Low & 30.3958 & 0.0463 & 0.0963 & 255161 \\
\hline $\begin{array}{c}\text { Manitoba } \\
\text { (Snow Lake) } \\
\text { Naosap herd } \\
35326\end{array}$ & R.t. caribou & Boreal & Small & Low & 34.9286 & 0.0358 & 0.0367 & 152613 \\
\hline
\end{tabular}


bioRxiv preprint doi: https://doi.org/10.1101/2020.12.29.424772; this version posted December 30, 2020. The copyright holder for this preprint (which was not certified by peer review) is the author/funder, who has granted bioRxiv a license to display the preprint in perpetuity. It is made available under aCC-BY-NC-ND 4.0 International license.

\begin{tabular}{|c|c|c|c|c|c|c|c|c|}
\hline $\begin{array}{c}\text { Manitoba } \\
\text { Qamanirijuaq } \\
\text { herd } 21332\end{array}$ & $\begin{array}{c}R . t . \\
\text { groenlandicus }\end{array}$ & $\begin{array}{l}\text { Barren- } \\
\text { ground }\end{array}$ & Large & Low & 31.8765 & -0.0833 & 0.0123 & 164607 \\
\hline $\begin{array}{c}\text { Manitoba } \\
\text { Qamanirijuaq } \\
\text { herd } 21350\end{array}$ & $\begin{array}{c}R . t . \\
\text { groenlandicus }\end{array}$ & $\begin{array}{l}\text { Barren- } \\
\text { ground }\end{array}$ & Large & Low & 30.7167 & -0.0868 & 0.0137 & 152570 \\
\hline $\begin{array}{c}\text { Quebec } \\
\text { George River } \\
\text { herd } 27689\end{array}$ & R.t. caribou & $\begin{array}{l}\text { Eastern } \\
\text { migratory }\end{array}$ & Medium & Low & 31.6268 & 0.0576 & 0.0689 & 208165 \\
\hline $\begin{array}{c}\text { Quebec } \\
\text { George River } \\
\text { herd } 27694\end{array}$ & R.t. caribou & $\begin{array}{l}\text { Eastern } \\
\text { migratory }\end{array}$ & Medium & Low & 32.3503 & 0.0330 & 0.0534 & 151553 \\
\hline $\begin{array}{c}\text { Ontario Pen } \\
\text { Island herd } \\
20917\end{array}$ & R.t. caribou & $\begin{array}{l}\text { Eastern } \\
\text { migratory }\end{array}$ & Medium & Low & 29.4896 & 0.0062 & 0.0598 & 151538 \\
\hline $\begin{array}{c}\text { Ontario Pen } \\
\text { Island herd } \\
34590\end{array}$ & R.t. caribou & $\begin{array}{l}\text { Eastern } \\
\text { migratory }\end{array}$ & Medium & Low & 31.5274 & 0.0276 & 0.0679 & 211619 \\
\hline $\begin{array}{c}\text { Western } \\
\text { Greenland } \\
\text { Kangerlussuaq } \\
41660\end{array}$ & $\begin{array}{c}R . t . \\
\text { groenlandicus }\end{array}$ & $\mathrm{n} / \mathrm{a}$ & Small & High & 33.1561 & 0.5800 & 0.3373 & 308640 \\
\hline $\begin{array}{c}\text { Western } \\
\text { Greenland } \\
\text { Kangerlussuaq } \\
41667\end{array}$ & $\begin{array}{c}R . t . \\
\text { groenlandicus }\end{array}$ & $\mathrm{n} / \mathrm{a}$ & Small & High & 30.3475 & 0.5877 & 0.5017 & 433852 \\
\hline
\end{tabular}




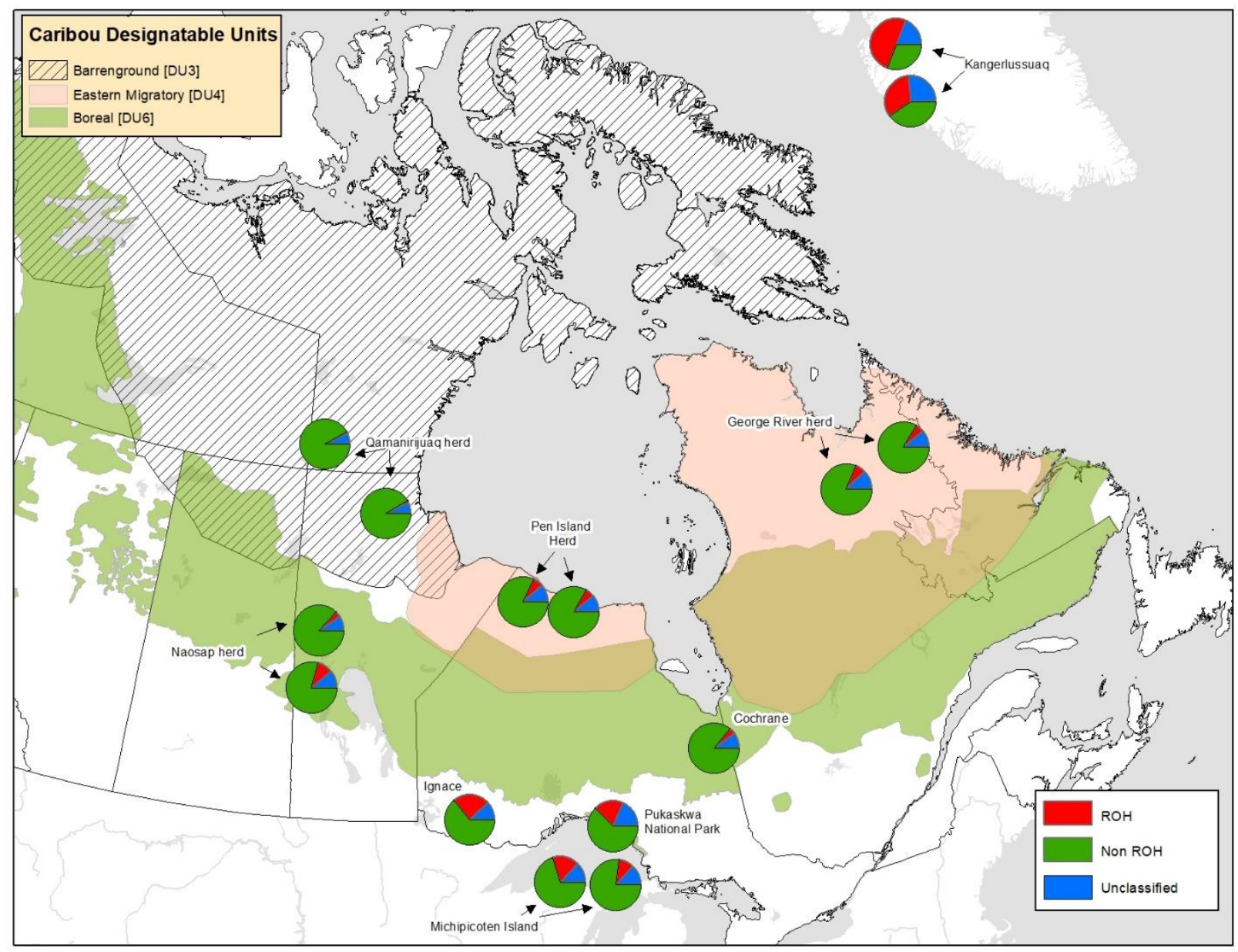

678 FIGURE 1 Sample sites of caribou in this study. Background colours show the ranges of the 679 three Canadian designatable units included: barren-ground, eastern migratory, and boreal. Labels on map reflect caribou population names. Pie charts represent the genomic level of inbreeding as the proportion of the genome in $\mathrm{ROH}$, non- $\mathrm{ROH}$, or unclassified for each individual $(\mathrm{N}=15)$, at the location that each sample was collected. 


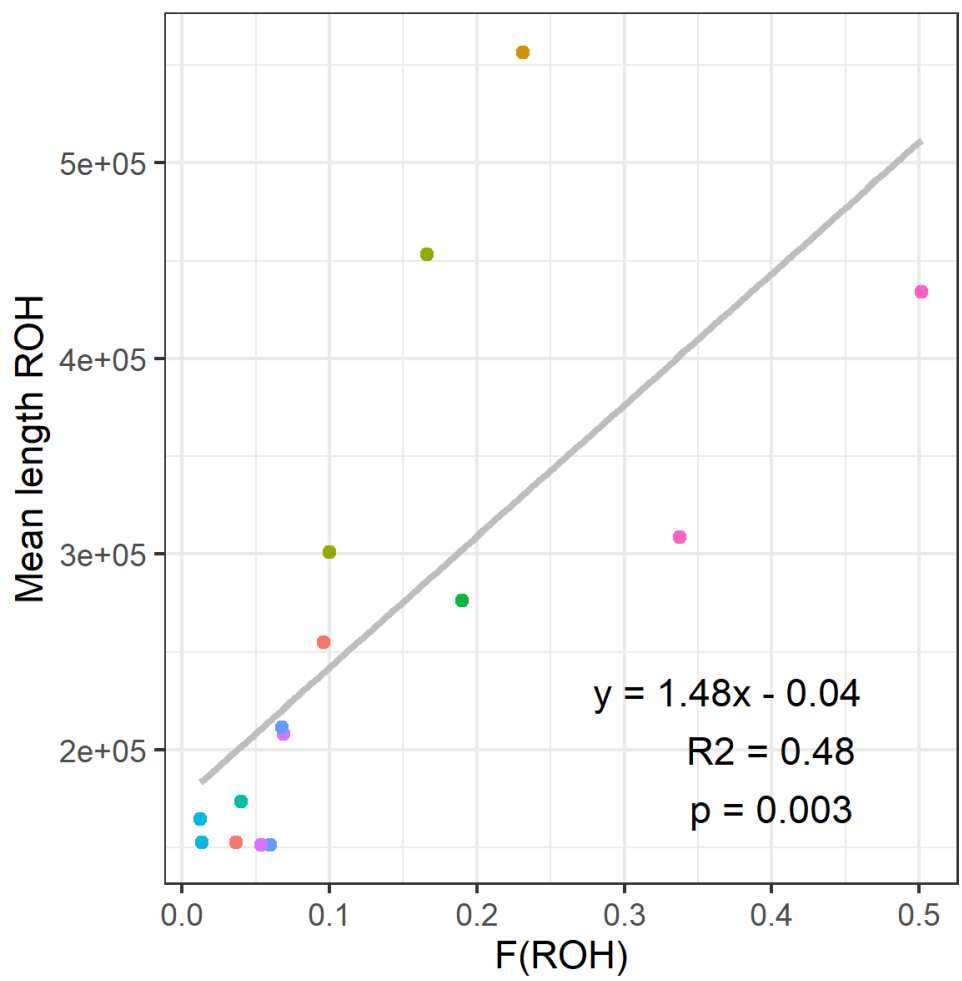

\section{Population}

- Naosap, Manitoba

- Ignace, Ontario

- Michipicoten, Ontario

- Pukaskwa, Ontario

- Cochrane, Ontario

- Qamanirijuaq, Manitoba

- Pen Island, Ontario

- George River, Quebec

- Kangerlussuaq, Greenland

FIGURE 2 Proportion of the genome in $\mathrm{ROH}\left(\mathrm{F}_{\mathrm{ROH}}\right)$ versus average length of $\mathrm{ROH}$ for each caribou based on high coverage whole genome sequences. Individuals are coloured by the population they were sampled from. The equation describes the line of best fit and $\mathrm{R}^{2}$ is the adjusted R-squared value.

690

691 

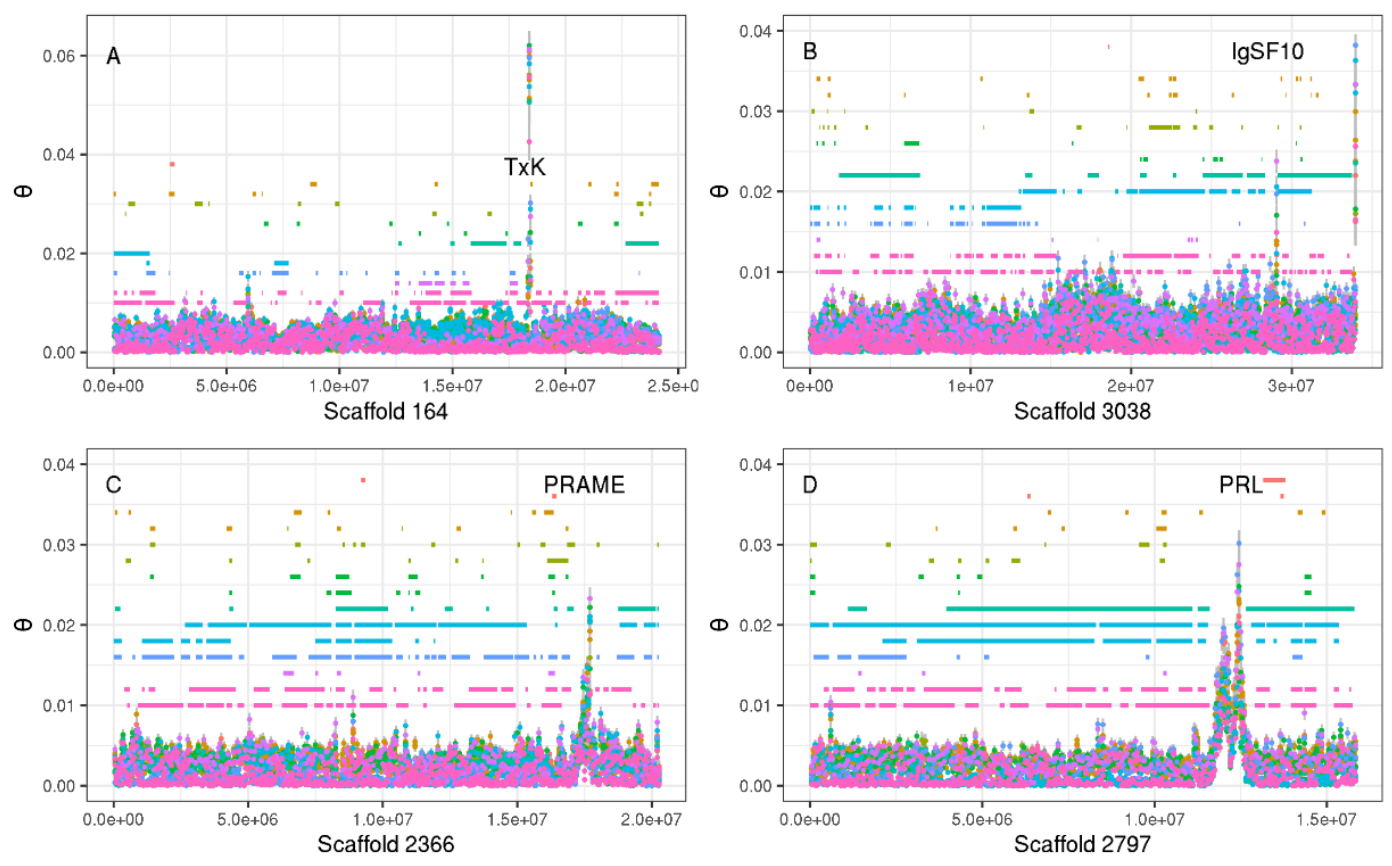

Population

- Qamanirijuaq, Manitoba

- George River, Quebec

- Pen Island, Ontario

Naosap, Manitoba

Ignace, Ontario

Michipicoten, Ontario

Pukaskwa, Ontario

Cochrane, Ontario

Kangerlussuaq, Greenland
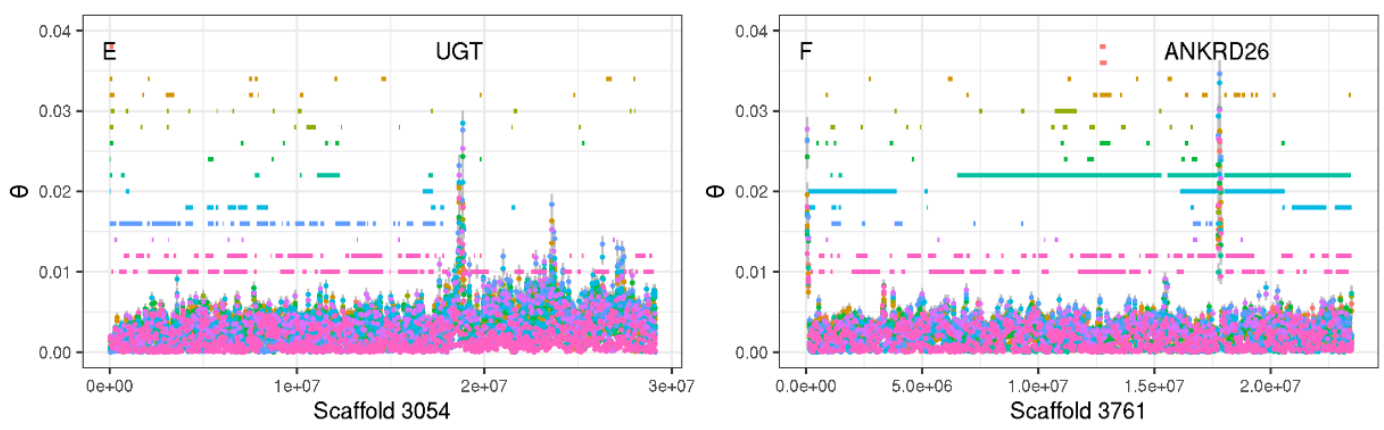

693 FIGURE 3 Heterozygosity estimates and Runs of Homozygosity (ROH) across select scaffolds

694 of the caribou genome. Points represent local heterozygosity estimates calculated as Waterson's $\theta$

695 every $50 \mathrm{~kb}$ for each individual, with standard error bars. Horizontal line segements represent

696 locations of ROH predicted by a hidden markov model for each individual. Colours represent

697 caribou populations. Annotated labels on plots refer to genes identified within islands of

698 heterzygosity. Note the Y-axis of plot A is 0.06; the Y-axes of plots B-F is 0.04 . 